\title{
Composition of sand fly fauna (Diptera: Psychodidae) and detection of Leishmania DNA (Kinetoplastida: Trypanosomatidae) in different ecotopes from a rural settlement in the central Amazon, Brazil
}

Erica Cristina da Silva Chagas ${ }^{1,2,3}$, Arineia Soares Silva ${ }^{1,2}$, Nelson Ferreira Fé2 ${ }^{2}$ Lucas Silva Ferreira ${ }^{2}$, Vanderson de Souza Sampaio ${ }^{3}$, Wagner Cosme Morhy Terrazas ${ }^{3}$, Jorge Augusto Oliveira Guerra 1,2, Rodrigo Augusto Ferreira de Souza ${ }^{1}$, Henrique Silveira ${ }^{4}$ and Maria das Graças Vale Barbosa Guerra ${ }^{1,2^{*}}$

\begin{abstract}
Background: Phlebotomine sand flies (Diptera: Psychodidae) are vectors of Leishmania species, the etiological agents of leishmaniasis, which is one of the most important emerging infectious diseases in the Americas. In the state of Amazonas in Brazil, anthropogenic activities encourage the presence of these insects around rural homes. The present study aimed to describe the composition and distribution of sand fly species diversity among the ecotopes (intradomicile, peridomicile and forest) in an area of American cutaneous leishmaniasis transmission and detect natural infection with Leishmania DNA to evaluate which vectors are inside houses and whether the presence of possible vectors represents a hazard of transmission.

Results: Phlebotomine sand flies were collected using light traps. A total of 2469 specimens representing 54 species, predominantly females (71.2\%), were collected from four sites. Polymerase chain reaction analysis was performed on 670 samples to detect Leishmania DNA. Most of the samples (79.5\%) were collected in the forest, with areas closer to rural dwellings yielding a greater abundance of suspected or proven vectors and a larger number of species containing Leishmania DNA. Nyssomyia umbratilis and Bichromomyia flaviscutellata were found near rural homes, and Ny. umbratilis was also found inside homes. Leishmania DNA was detected in different species of sand flies in all ecotopes, including species with no previous record of natural infection.
\end{abstract}

Conclusions: There is no evidence that vectors of American cutaneous leishmaniasis are becoming established inside homes, but there are sand flies, including $\mathrm{Ny}$. umbratilis and other possible vectors, in environments characterized by a human presence. These species continue to be predominant in the forest but are prevalent in areas closer to ecotopes with a greater human presence. The existence of proven or suspected vectors in this ecotope is due to the structural organization of rural settlements and may represent a hazard of transmission. Although the detection of Leishmania DNA in species that were not previously considered vectors does not mean that they are transmitting the parasite, it does show that the parasite is circulating in ecotopes where these species are found.

Keywords: Vectors of Leishmania, Leishmania DNA, Sand fly diversity and richness, Amazon region, Brazil

\footnotetext{
* Correspondence: mgvale@uea.edu.br

'Universidade do Estado do Amazonas (Programa de Pós-graduação em

Medicina Tropical/Programa de Pos-graduação em Clima e Ambiente),

Manaus, Amazonas, Brasil

${ }^{2}$ Fundação de Medicina Tropical Dr. Heitor Vieira Dourado, Manaus,

Amazonas, Brasil

Full list of author information is available at the end of the article
} 


\section{Background}

Phlebotomine sand flies (Diptera: Psychodidae) are important vectors of human diseases that have a great impact on public health, mainly as vectors of Leishmania species, the etiological agents of leishmaniasis [1]. This disease is endemic in 98 countries, posing a risk to an estimated 350 million people and infecting 0.7-1.2 million people annually [2-4]. Leishmaniasis is one of the most important emerging infectious diseases in the Americas [5].

There are approximately 1000 phlebotomine sand fly species, but only 98 species are proven or suspected vectors of human leishmaniasis. Phlebotomine sand flies in America include approximately 530 valid species, of which 135 species have been recorded in the state of Amazonas, Brazil [6-8]. The species of sand flies that have been described as the main vectors of American cutaneous leishmaniasis (ACL) in the Amazonas are Nyssomyia umbratilis and Ny. anduzei, which are vectors of Leishmania (Viannia) guyanensis, and Bichromomyia flaviscutellata and Bi. olmeca nociva, which are vectors of L. (Leishmania) amazonensis [9-11]. L. (V.) guyanensis is the most prevalent species in the region [12].

Previous studies have shown the presence of proven or putative vectors, mainly in the forest but also near houses. In the municipality of Manaus, the capital of Amazonas, in the western region of the Amazon basin, Feitosa \& Castellón [13] observed the presence these insects also in the intradomicile and peridomicile areas of housing complexes near forest fragments. Moreover, Barbosa et al. [14] showed Ny. umbratilis could be observed in peridomicile areas of a rural community. Figueira et al. [15] collected most sand flies in peridomicile areas of a neighbourhood, a rural settlement, and two indigenous settlements in the Labrea municipality. Reis et al. [16] investigated natural Leishmania infection in sand flies collected in peridomiciles in a neighbourhood in Manaus near a forest reserve; however, the results were negative. These findings, in addition to the fact that some areas in Brazil show a change in ACL transmission patterns, such as the adaptation of some sand flies to the peridomiciliary environment [17], emphasize the importance of studies of the composition and distribution of sand flies in the Amazon region.

In Manaus, areas of ACL occurrence are associated with deforestation, the presence of houses on the outskirts of the forest and the presence of synanthropic animals near households. To address ACL, it is important to understand the composition and diversity of phlebotomine species, particularly in environments with greater anthropogenic pressure, such as the peridomicile and intradomicile. Thus, the present study aimed to describe the composition and distribution of sand fly species diversity among ecotopes (intradomicile, peridomicile and forest) in an area of ACL transmission, as well as to detect natural infection with Leishmania DNA, in order to evaluate which vectors are inside houses and whether they represent a hazard of transmission.

\section{Methods \\ Study area}

The study was conducted in a rural area of Manaus, northern Brazil, in the western Amazon (Fig. 1a). Manaus has an area of 11,401.092 $\mathrm{km}^{2}$ and an estimated 2,094,400 inhabitants [18]. In this region, leishmaniasis cases are concentrated in rural areas, such as the Tarumã Mirim Rural Settlement $\left(2.792972^{\circ} \mathrm{S}, 60.036966^{\circ} \mathrm{W}\right)$, an important autochthonous transmission area. This settlement contains 42,910.76 hectares and is located northwest to Manaus, between the Tarumã Mirim and Tarumã Açu basins. The settlement is formed by two main branches, Ramal do Pau Rosa and Ramal da Cooperativa, from which numerous branch roads originate.

The predominant vegetation cover is ombrophile forest, with anthropogenic activities being quite intensive and including agricultural crops, coal production, livestock and secondary vegetation. The climate of the region is type "A" (Köppen classification), presenting two climatic variations: Af and Amw, hot and wet climates. The average annual temperature is $27{ }^{\circ} \mathrm{C}$ with a small thermal amplitude. The atmospheric humidity varies between $75-86 \%$, and pluviometric indexes range between $1750-2500 \mathrm{~mm}$ a year $[19,20]$.

For the study, four fixed collection points were established along the two main branches (Fig. 1b), in dwellings where there was a record of at least one autochthonous case of ACL in the six months prior to the study.

\section{Phlebotomine sand fly collection and species identification} Phlebotomine sand flies were collected using 16 CDC (Centers for Disease Control and Prevention) light traps installed $1 \mathrm{~m}$ off the ground, for three consecutive days from 5:00 pm to 7:00 am, between May 2015 and April 2016, totalling 9216 hours of sampling effort. At each fixed point of collection, the traps were installed as follows: one intradomicile, one peridomicile and two in the forest (100 $\mathrm{m}$ and $400 \mathrm{~m}$ from the edge of the forest, denoted $\mathrm{F} 100 \mathrm{~m}$ and $\mathrm{F} 400 \mathrm{~m}$, respectively). The distance from the edge of the forest to the dwellings varied greatly according to the fixed point of collection, ranging between 30-170 meters.

The collected males and body parts of the females (head and the last two abdominal segments) were mounted on glass slides with Berlese liquid and identified according to their external morphological characteristics, using the key developed by Young \& Duncan [21] 

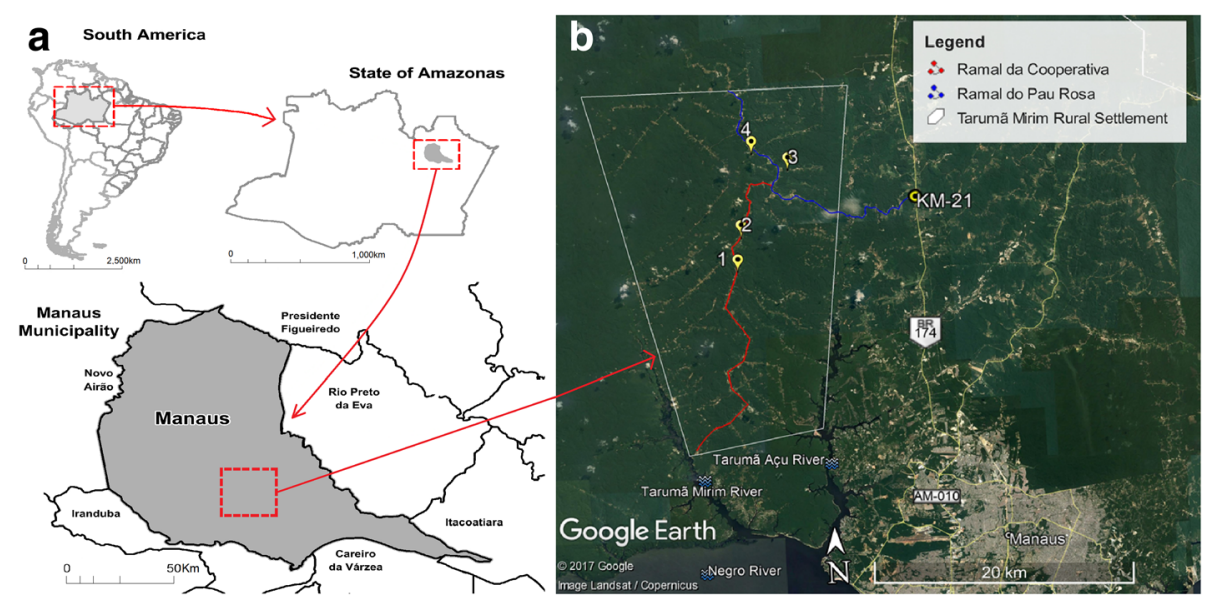

Fig. 1 Map of the study area. a Location of collection area (Tarumã Mirim Rural Settlement) in Manaus Municipality, Amazonas State, Brazil. Source: CDC [48]. b Tarumã Mirim Rural Settlement with location of fixed collection points to sand fly sampling: Ramal da Cooperativa (red), points 1 and 2, and Ramal do Pau Rosa (blue), points 3 and 4. Source: Google Earth [49]

and Galati [22] and generic abbreviations proposed by Marcondes [23]. The thoraces and abdomen parts of the females were stored in $80 \%$ ethyl alcohol and kept at $-20{ }^{\circ} \mathrm{C}$ for subsequent molecular analysis to detect Leishmania DNA.

\section{Detection of Leishmania DNA}

To detect Leishmania DNA in phlebotomine sand flies, only non-engorged and egg-free females were used, in order to minimize the detection of the parasite in undigested blood [24]. Females were individually processed or grouped into pools of up to 10 specimens, organized according to species, ecotope, collection point and date. A total of 670 samples were formed for molecular analysis, including individual and pooled specimens.

DNA extraction was performed in pools of 5-10 specimens, using the Purelink ${ }^{\text {tw }}$ Genomic DNA Mini Kit (Invitrogen, Carlsbad, USA), following the manufacturer's instructions. However, for individual phlebotomine sand flies and pools of 2-4 specimens, DNA extraction was done with $\mathrm{Chelex}^{\circ} 100$ resin (BioRad, Hercules, USA) because through this technique, it is possible to extract a greater amount of DNA. During the process of DNA extraction, every 10 samples included a blank to confirm that the samples were not contaminated.

Leishmania DNA was detected using multiplex polymerase chain reaction (PCR), using as target DNA: (i) a mini-circle of kDNA (116 bp) for identification of the genus Leishmania, using the primers 13a (5'-GTG GGG GAG GGG CGT TCT-3') and 13b (5'-ATT TTA CAC CAA CCC CCA GTT-3') [25]; and (ii) a fragment of the cox 1 gene (658 bp) to identify DNA from sand flies and confirm the quality of DNA extraction, using the primers LCO1490 (5'-GGT CAA CAA ATC ATA AAG ATA TTG G-3') and HCO2198 (5'-TAA ACT TCA GGG TGA CCA
AAA AAT CA-3') [26]. The reaction mixture contained 5 $\mu \mathrm{L}$ of extracted DNA, $0.15 \mu \mathrm{L}$ of each primer $(0.4 \mu \mathrm{M})$, $0.75 \mu \mathrm{L}$ of $\mathrm{MgCl}_{2}(3.5 \mu \mathrm{M}), 0.5 \mu \mathrm{L}$ of dNTPs $(0.2 \mathrm{mM}), 1$ $\mathrm{U}$ Taq polymerase and Buffer $1 \times$, for a total volume of 25 $\mu \mathrm{l}$. The multiplex reaction was performed with an initial denaturation of $94{ }^{\circ} \mathrm{C}$ for $4 \mathrm{~min}$, followed by 10 cycles of $94{ }^{\circ} \mathrm{C}, 60{ }^{\circ} \mathrm{C}$, and $72{ }^{\circ} \mathrm{C}, 1 \mathrm{~min}$ each and 20 cycles of $94{ }^{\circ} \mathrm{C}$, $50{ }^{\circ} \mathrm{C}$, and $72^{\circ} \mathrm{C}, 1 \mathrm{~min}$ each. The final extension was performed at $72{ }^{\circ} \mathrm{C}$ for $5 \mathrm{~min}$. In each reaction, a no-template control was included, as well as positive controls for phlebotomine and Leishmania reference strain DNA.

The reaction products were subjected to $2 \%$ agarose gel electrophoresis in $1 \times \mathrm{TBE}$, stained with ethidium bromide. The approximate size of the amplification product, in terms of base pairs, was determined by comparison with a $100 \mathrm{bp}$ and $50 \mathrm{bp}$ marker. The amplified products were visualized under ultraviolet light and subsequently photographed.

\section{Statistical analysis}

Quantification of phlebotomine sand flies collected in the study area was expressed through absolute abundance, relative abundance and standardized index of species abundance. The Standardized Index of Species Abundance (SISA) was calculated as described by Roberts \& Hsi [27]. SISA values range from 0 to 1 , and species abundance was considered high when the SISA value was close to the maximum value of 1 . Species diversity was assessed using the Shannon's Index $\left(\mathrm{H}^{\prime}\right)$, calculated with Diversidade de Espécies (DivEs) software version 4.0 (http://dives.ebras.bio.br/guide_dives.aspx). The distribution of species in the study period was calculated by the Constancy Index according to Silveira Neto et al. [28], which classifies species as constants (when present in more than 50\% of collections), 
accessory (present in $25-50 \%$ of collections), or accidental (present in less than $25 \%$ of collections). Abundance and Shannon's index values were compared between ecotopes using the Student's t-test to determine significance, performed with Stata software v. 13. The minimum infection rate was calculated with the following formula: number of positive pools $\times 100 /$ total number of females in pool $[29,30]$. Maps were generated using the software MapInfo Pro ${ }^{\text {TM }}$ v. 16.

\section{Results}

A total of 2469 phlebotomine sand flies were collected, representing 54 species and 13 genera: Psychodopygus (Ps., 10 spp.), Psathyromyia (Pa., 9 spp.), Evandromyia (Ev., 8 spp.), Lutzomyia (Lu., 4 spp.), Micropygomyia (Mi., 3 spp.), Nyssomyia (Ny., 3 spp.), Sciopemyia (Sc., 3 spp.), Trichopygomyia (Ty., 3 spp.), Bichromomyia (Bi., 2 spp.), Migonemyia (Mg., 2 spp.), Pressatia (Pr., 2 spp.), Trichophoromyia (Th., 2 spp.), Viannamyia (Vi., 2 spp.), and Pintomyia (Pi., 1 sp.) (Table 1).

The most abundant species were Ty. trichopyga (19.9\%; 4th rank SISA), Mi. rorotaensis (16.3\%; 1st rank SISA), $N y$. umbratilis (13\%; 2nd rank SISA), Sc. sordellii (9.6\%; 3rd rank SISA), $N y$. anduzei (6.7\%; 5th rank SISA) and Ps. davisi (4.7\%; 9th rank SISA), which together comprised $70.1 \%$ of the total specimens captured (Table 1 ). The male/ female ratio was 0.40 , with $71.2 \%$ females and $28.8 \%$ males.

The greatest abundance and species richness was observed in the forest environment. In the $\mathrm{F} 400 \mathrm{~m}$ area, 1027 (41.6\%) specimens and 49 species were collected. The predominant species were Ty. trichopyga (392 specimens, 38.2\%), Mi. rorotaensis (108 specimens, 10.5\%) and $N y$. umbratilis (103 specimens, $10 \%$ ). In the $\mathrm{F} 100 \mathrm{~m}$ area, 935 (37.9\%) specimens and 42 species were collected, with a predominance of $\mathrm{Mi}$. rorotaensis (212 specimens, 22.7\%), followed by $N y$. umbratilis (157 specimens, $16.8 \%$ ) and $N y$. anduzei (93 specimens, 9.9\%).

The peridomicile showed 261 (10.6\%) specimens and 36 species. The most abundant species was Sc. sordellii (63 specimens, 24.1\%), followed by $N y$. umbratilis (41 specimens, 15.7\%) and Ev. sericea (34 specimens, 13\%). In the intradomicile area, $246(10 \%)$ specimens and 29 species were collected. Sciopemyia sordellii (102 specimens, $41.5 \%$ ) was predominant, followed by Mi. rorotaensis (58 specimens, 23.6\%) and Ny. umbratilis (20 specimens, $8.1 \%$ ) (Table 1).

A comparison of the mean phlebotomine sand fly abundance during the total collection time revealed a statistical difference between intradomicile and F100m $\quad\left(t_{(20)}=-2.49, \quad P=0.01\right) ; \quad$ intradomicile and F400m $\quad\left(t_{(20)}=-1.92, \quad P=0.03\right) ; \quad$ peridomicile and F100m $\left(t_{(22)}=-3.26, P=0.002\right)$; and peridomicile and F400m $\left(t_{(22)}=-2.33, P=0.01\right)$ (Fig. 2).
The ecotope that had the highest diversity was F100m $\left(\mathrm{H}^{\prime}=3.93\right)$, followed by the peridomicile $\left(\mathrm{H}^{\prime}=3.81\right)$. The comparison of the average diversity for total collection time showed a statistical difference between intradomicile and peridomicile $\left(t_{(22)}=-2.46, P=0.01\right)$; intradomicile and F100m $\left(t_{(22)}=-3.90, P=0.0004\right)$; intradomicile and $\mathrm{F} 400 \mathrm{~m}\left(t_{(22)}=-4.78, P<0.0001\right)$; peridomicile and F100m $\left(t_{(22)}=-1.81, P=0.04\right)$; and peridomicile and F400m $\left(t_{(22)}=-2.83, P=0.005\right)$ (Fig. 3).

Among the species suspected or proven to be vectors, Bi. olmeca nociva, Ny. anduzei, Ny. antunesi, Ny. umbratilis, Ps. davisi and Ps. sq. squamiventris were found in all evaluated ecotopes. Bichromomyia flaviscutellata, Ps. ayrozai and Ps. paraensis were found in the peridomicile and in the forest. Lutzomyia gomezi was present in the intradomicile and in the forest, and $M g$. migonei was found exclusively in the forest. Bichromomyia olmeca nociva, Ny. anduzei, Ny. umbratilis and Ps. davisi were classified using the constancy index as constant species throughout the study period (Table 2).

Various species of phlebotomine sand flies tested positive for Leishmania DNA in all ecotopes evaluated (Table 3). Of the 670 analysed samples, 54 (8.1\%) samples belonging to 21 phlebotomine species were positive for the presence of Leishmania DNA. Nyssomyia umbratilis and $N y$. anduzei had minimum infection rates of $2.7 \%$ and $6.2 \%$, respectively.

\section{Discussion}

Our samples included 54 species of phlebotomine sand fly among the 67 species registered in Manaus and nearby municipalities [17]. These species were distributed between the intradomicile, peridomicile and forest. The majority of sand fly fauna was captured in forest environments, which was expected because the species prefer a primarily wild habit. Other studies carried out in different areas of Manaus forests also found high species richness, such as those by Arias \& Freitas [31], Castellón et al. [32], Dias-Lima [33], Barbosa et al. [14] and Gomes et al. [34], who found 50, 57, 39, 49 and 58 species of sand fly, respectively. Our findings showed a high species richness of phlebotomine sand flies in the Tarumã Mirim Rural Settlement. Located in the northwest of Manaus, this settlement is an important autochthonous transmission ACL area.

The most abundant species found in the study were Ty. trichopyga, Mi. rorotaensis, Ny. umbratilis, Sc. sordellii, Ny. anduzei and Ps. davisi. Of these species, $N y$. umbratilis, $N y$. anduzei and Ps. davisi have already been associated with ACL transmission. In the Amazonas State, four species have been confirmed as vectors of ACL: Ny. umbratilis, Ny. anduzei, Bi. flaviscutellata and Bi. olmeca nociva [14, 31, 35]. These species of sand flies were found in this study and tested 
Table 1 Species of sand flies from Tarumã Mirim Rural Settlement, Manaus Municipality, Amazonas State, Brazil, collected with CDC light traps from May 2015 to April 2016

\begin{tabular}{|c|c|c|c|c|c|c|c|c|c|c|c|c|c|}
\hline \multirow[t]{2}{*}{ Species [Reference] } & \multicolumn{2}{|l|}{ Id } & \multicolumn{2}{|l|}{$\mathrm{Pd}$} & \multicolumn{2}{|c|}{ F100m } & \multicolumn{2}{|c|}{$\mathrm{F} 400 \mathrm{~m}$} & \multirow[t]{2}{*}{ Total } & \multirow[t]{2}{*}{$\%$} & \multirow[t]{2}{*}{ Ratio M/F } & \multirow[t]{2}{*}{ SISA } & \multirow[t]{2}{*}{ Rank } \\
\hline & M & $\mathrm{F}$ & M & $\mathrm{F}$ & $\mathrm{M}$ & $\mathrm{F}$ & M & $\mathrm{F}$ & & & & & \\
\hline Ty. trichopyga Floch \& Abonnenc, 1945 & 10 & 2 & 8 & 4 & 28 & 48 & 209 & 183 & 492 & 19.9 & 1.08 & 0.9 & 4 \\
\hline Mi. rorotaensis Floch \& Abbonenc, 1944 & 5 & 53 & 3 & 21 & 27 & 185 & 23 & 85 & 402 & 16.3 & 0.17 & 1.0 & 1 \\
\hline Ny. umbratilis Ward \& Fraiha, $1977^{\mathrm{a}}[2,40,41]$ & 4 & 16 & 28 & 13 & 45 & 112 & 54 & 49 & 321 & 13.0 & 0.69 & 1.0 & 2 \\
\hline Sc. sordellii Shannon \& Del Ponte, 1927 & 8 & 94 & 3 & 60 & 12 & 22 & 3 & 34 & 236 & 9.6 & 0.12 & 0.9 & 3 \\
\hline Ny. anduzei Rozeboom, $1942^{\mathrm{a}}[2,41]$ & 1 & 8 & - & 4 & 4 & 89 & 10 & 49 & 165 & 6.7 & 0.10 & 0.9 & 5 \\
\hline Ps. davisi Root, $1934^{\mathrm{a}}[42,43]$ & - & 1 & 1 & 7 & 12 & 75 & 4 & 16 & 116 & 4.7 & 0.17 & 0.8 & 9 \\
\hline Ev. sericea Floch \& Abbonenc, 1944 & 1 & 4 & 16 & 18 & 7 & 5 & 1 & 9 & 61 & 2.5 & 0.69 & 0.8 & 8 \\
\hline Sc. nematoducta Young \& Arias, 1984 & 3 & 5 & 5 & 3 & 7 & 7 & 10 & 12 & 52 & 2.1 & 0.93 & 0.8 & 6 \\
\hline Ev. georgii Freitas \& Barrete, 2002 & - & 3 & - & 9 & - & 16 & - & 22 & 50 & 2.0 & - & 0.8 & 7 \\
\hline Ps. geniculatus Mangabeira, 1941 & - & - & 5 & 1 & 2 & 32 & 4 & 1 & 45 & 1.8 & 0.32 & 0.5 & 19 \\
\hline Bi. olmeca nociva Young \& Arias, $1982^{a}[2,41]$ & - & 1 & - & 1 & - & 8 & 1 & 30 & 41 & 1.7 & 0.03 & 0.6 & 18 \\
\hline Pr. triacantha Mangabeira, 1942 & - & 4 & 1 & 2 & 1 & 7 & 8 & 17 & 40 & 1.6 & 0.33 & 0.7 & 10 \\
\hline PS. sq. squamiventris Lutz \& Neiva, $1912^{\mathrm{a}}[2]$ & - & 1 & 1 & - & 6 & 7 & 2 & 21 & 38 & 1.5 & 0.31 & 0.6 & 13 \\
\hline Mi. micropyga Mangabeira, 1942 & - & 1 & - & 1 & - & 21 & - & 13 & 36 & 1.5 & - & 0.6 & 15 \\
\hline Th. eurypyga Martins, Falcão \& Silva, 1963 & - & 1 & 2 & - & 1 & 6 & 10 & 7 & 27 & 1.1 & 0.93 & 0.6 & 17 \\
\hline Ev. monstruosa Floch \& Abonnenc, 1944 & - & 1 & - & 4 & 2 & 8 & - & 11 & 26 & 1.1 & 0.08 & 0.7 & 11 \\
\hline Pa. dendrophyla Mangabeira, 1942 & - & 1 & 10 & - & 2 & 7 & 2 & 3 & 25 & 1.0 & 1.27 & 0.6 & 12 \\
\hline Pr. trispinosa Mangabeira, 1942 & - & - & 1 & - & 1 & - & 22 & - & 24 & 1.0 & - & 0.3 & 27 \\
\hline PS. corossoniensis Le Pont \& Pajot, 1978 & - & 2 & - & - & - & 16 & - & 4 & 22 & 0.9 & - & 0.5 & 20 \\
\hline Bi. flaviscutellata Mangabeira, $1942^{a}[2,40,41]$ & - & - & - & 2 & 2 & 12 & 1 & 5 & 22 & 0.9 & 0.16 & 0.5 & 21 \\
\hline Pa. aragaoi Costa Lima, 1932 & - & - & 2 & - & 4 & 5 & 7 & 4 & 22 & 0.9 & 1.44 & 0.5 & 22 \\
\hline Ny. antunesi Coutinho, $1939^{a}[2,40]$ & - & 3 & - & 7 & - & 6 & - & 5 & 21 & 0.9 & - & 0.6 & 14 \\
\hline Th. ruii Arias \& Young, 1982 & 1 & - & - & 2 & 11 & - & 5 & 2 & 21 & 0.9 & 4.25 & 0.6 & 16 \\
\hline Vi. tuberculata Floch e Abonnenc, 1941 & - & - & - & - & - & 9 & - & 10 & 19 & 0.8 & - & 0.3 & 29 \\
\hline Lu. evangelistai Martins \& Fraiha, 1971 & - & 1 & - & - & - & 7 & - & 7 & 15 & 0.6 & - & 0.4 & 25 \\
\hline Vi. furcata Mangabeira, 1941 & 1 & - & - & 1 & 1 & 7 & 1 & 3 & 14 & 0.6 & 0.27 & 0.5 & 23 \\
\hline Ps. paraensis Costa Lima, $1941^{\mathrm{a}}[2,40]$ & - & - & 1 & - & - & 7 & - & 6 & 14 & 0.6 & 0.08 & 0.4 & 26 \\
\hline Mi. pilosa Damasceno \& Causey, 1944 & - & 1 & - & 1 & - & 3 & - & 4 & 9 & 0.4 & - & 0.4 & 24 \\
\hline Pa. shannoni Dyar, 1929 & - & - & 1 & 1 & 2 & 2 & 2 & - & 8 & 0.3 & 1.67 & 0.3 & 30 \\
\hline Lu. gomezi Nitzulescu, $1931^{\mathrm{a}}[2,40]$ & - & 1 & - & - & 2 & 3 & 2 & - & 8 & 0.3 & 1.00 & 0.3 & 32 \\
\hline Ps. hi. hirsutus Mangabeira, 1942 & - & - & - & 1 & 1 & 5 & - & 1 & 8 & 0.3 & 0.14 & 0.2 & 37 \\
\hline Ps. ayrozai Barretto \& coutinho, $1942^{a}[2,40,41]$ & - & - & - & 1 & 3 & 1 & 1 & 1 & 7 & 0.3 & 1.33 & 0.2 & 33 \\
\hline Ps. claustrei Abonnenc, Léger \& Fauram, 1979 & - & - & - & 1 & - & 4 & 1 & 1 & 7 & 0.3 & 0.17 & 0.2 & 34 \\
\hline Pa. dreisbachi Causey \& Damasceno, 1945 & 1 & 2 & - & - & - & 1 & - & 2 & 6 & 0.2 & 0.20 & 0.3 & 31 \\
\hline PS. chagasi Costa Lima, 1941 & - & - & - & - & - & 2 & - & 4 & 6 & 0.2 & - & 0.2 & 40 \\
\hline Lu. falcata Young, Morales \& Ferro, 1994 & - & 1 & - & 1 & - & 1 & - & 2 & 5 & 0.2 & - & 0.3 & 28 \\
\hline Ty. ratcliffei Arias, Ready \& Freitas, 1983 & 1 & - & - & - & - & - & 3 & - & 4 & 0.2 & - & 0.2 & 36 \\
\hline Ps. amazonensis Root, 1934 & - & - & 1 & - & - & 1 & 1 & 1 & 4 & 0.2 & 1.00 & 0.2 & 38 \\
\hline Ty. longispina Mangabeira, 1943 & - & - & - & - & - & - & 2 & 2 & 4 & 0.2 & 1.00 & 0.1 & 44 \\
\hline Pa. inflata Floch \& Abonnenc, 1944 & 1 & - & - & 1 & - & - & 1 & - & 3 & 0.1 & 2.00 & 0.2 & 35 \\
\hline Mg. migonei França, $1920^{a}[2,40,41]$ & - & - & - & - & - & 1 & 1 & 1 & 3 & 0.1 & 0.50 & 0.1 & 45 \\
\hline Pa. lutziana Costa Lima, 1932 & - & 1 & - & - & 1 & - & - & - & 2 & 0.1 & 1.00 & 0.2 & 39 \\
\hline
\end{tabular}


Table 1 Species of sand flies from Tarumã Mirim Rural Settlement, Manaus Municipality, Amazonas State, Brazil, collected with CDC light traps from May 2015 to April 2016 (Continued)

\begin{tabular}{|c|c|c|c|c|c|c|c|c|c|c|c|c|c|}
\hline \multirow[t]{2}{*}{ Species [Reference] } & \multicolumn{2}{|l|}{ Id } & \multicolumn{2}{|l|}{$\mathrm{Pd}$} & \multicolumn{2}{|c|}{ F100m } & \multicolumn{2}{|c|}{$\mathrm{F} 400 \mathrm{~m}$} & \multirow[t]{2}{*}{ Total } & \multirow[t]{2}{*}{$\%$} & \multirow[t]{2}{*}{ Ratio M/F } & \multirow[t]{2}{*}{ SISA } & \multirow[t]{2}{*}{ Rank } \\
\hline & M & $\mathrm{F}$ & M & $\mathrm{F}$ & M & $\mathrm{F}$ & M & $\mathrm{F}$ & & & & & \\
\hline Pa. runoides Fairchild \& Hertig, 1953 & - & - & 2 & - & - & - & - & - & 2 & 0.1 & - & 0.2 & 41 \\
\hline Pa. barrettoi barrettoi Mangabeira, 1942 & - & - & 1 & - & - & - & 1 & - & 2 & 0.1 & - & 0.1 & 43 \\
\hline Pi. damascenoi Mangabeira, 1941 & - & - & - & - & - & - & - & 2 & 2 & 0.1 & - & 0.1 & 48 \\
\hline Ev. infraspinosa Mangabeira, 1941 & - & - & - & - & - & 1 & - & 1 & 2 & 0.1 & - & 0.1 & 49 \\
\hline Pa. scaffi Damasceno \& Arouck, 1956 & - & - & - & - & - & 1 & 1 & - & 2 & 0.1 & 1.00 & 0.1 & 50 \\
\hline Ev. williamsi Damasceno, Causey \& Arouck, 1945 & - & - & - & - & 1 & - & - & 1 & 2 & 0.1 & 1.00 & 0.1 & 51 \\
\hline Mg. moucheti Pajot \& Le Pont, 1978 & 1 & - & - & - & - & - & - & - & 1 & 0.0 & - & 0.1 & 42 \\
\hline Ev. pinottii Damasceno \& Arouck, 1956 & - & - & 1 & - & - & - & - & - & 1 & - & - & 0.1 & 46 \\
\hline Evandromyia sp. de Baduel Floch \& Abonnenc, 1945 & - & - & 1 & - & - & - & - & - & 1 & - & - & 0.1 & 47 \\
\hline Ev. inpai Young \& Arias, 1977 & - & - & - & - & - & - & - & 1 & 1 & - & - & 0.0 & 52 \\
\hline Sc. preclara Young \& Arias, 1984 & - & - & - & - & - & - & - & 1 & 1 & - & - & 0.0 & 53 \\
\hline Lu. spathotrichia Martins, Falcão \& Silva, 1963 & - & - & - & - & - & - & - & 1 & 1 & - & - & 0.0 & 54 \\
\hline Total & 38 & 208 & 94 & 167 & 185 & 750 & 393 & 634 & 2,469 & 100 & 0.40 & - & - \\
\hline
\end{tabular}

Abbreviations: Id intradomicile, $P d$ peridomicile, $F 100 \mathrm{~m}$ forest $100 \mathrm{~m}$ from edge, F400m forest $400 \mathrm{~m}$ from edge, $M$ male, $F$ female, SISA Standardized Index of Species Abundance

${ }^{a}$ Species that are suspected or proven vectors

positive for Leishmania DNA. Nyssomyia umbratilis and $N y$. anduzei had higher abundances and minimum infection rates at $2.7 \%$ and $6.2 \%$, respectively. These findings are in agreement with the observed epidemiological situation, as $L .(V$.$) guyanensis is the predomin-$ ant species both in the state of Amazonas and in Manaus [5, 12, 36].

Nyssomyia umbratilis, the primary vector of $L .(V$. guyanensis, is the main etiologic agent of ACL in Amazon and is associated with both cutaneous and mucosal forms

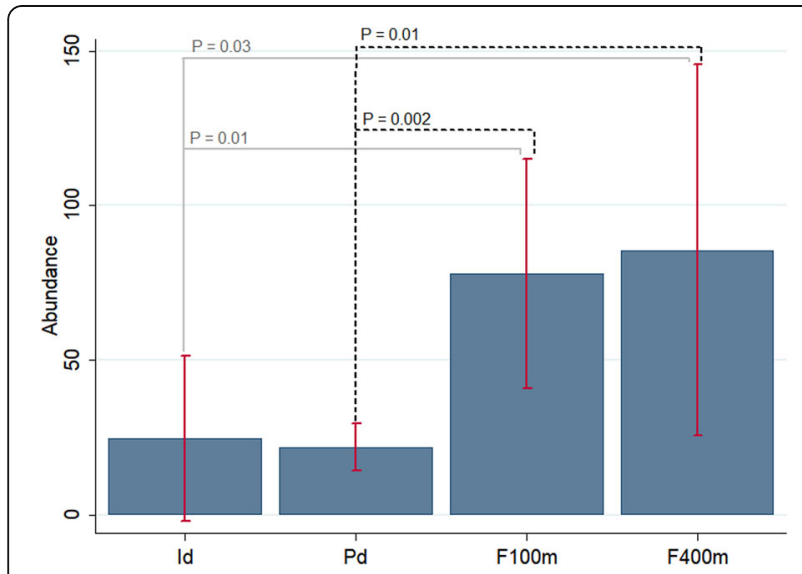

Fig. 2 Abundance of phlebotomine sand flies. Phlebotomine sand flies from Tarumã Mirim Rural Settlement, Manaus Municipality, Amazonas State, Brazil, collected May 2015 to April 2016, at the following sampling sites: intradomicile (Id), peridomicile (Pd), $100 \mathrm{~m}$ from the edge of the forest (F100m), and $400 \mathrm{~m}$ from the edge of the forest (F400m) of the disease [12, 15, 37]. This species is found primarily in forest environments but previously was recorded in intradomicile locations in the Amazonas state in only recently inhabited areas near residual forest [13], perhaps because the collection methods used by many surveys do not include the intradomicile. The presence of $N y$. umbratilis in the peridomicile was reported in: (i) Manaus, in a rural community (24 specimens) [38], and an area near residual forest (23 specimens) [16]; (ii) Presidente Figueiredo, in a rural settlement (38 specimens) [17]; and

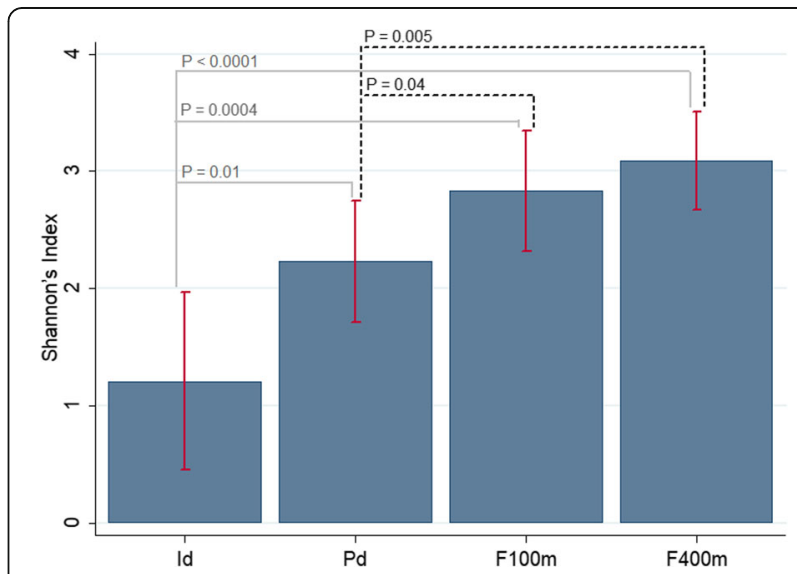

Fig. 3 Shannon's Index for phlebotomine sand flies. Phlebotomine sand flies from Tarumã Mirim Rural Settlement, Manaus Municipality, Amazonas State, Brazil, collected May 2015 to April 2016, at the following sampling sites: intradomicile (Id), peridomicile (Pd), $100 \mathrm{~m}$ from the edge of the forest (F100m) and $400 \mathrm{~m}$ from the edge of the forest (F400m) 
Table 2 Constancy index for species suspected or proven to be vectors from Tarumã Mirim Rural Settlement, Manaus Municipality, Amazonas State, Brazil, collected with CDC light traps from May 2015 to April 2016

\begin{tabular}{lll}
\hline Suspected or proven vectors & Constancy index & Status \\
\hline Bichromomyia flaviscutellata & 30.6 & Accessory \\
Bichromomyia olmeca nociva & 52.8 & Constant \\
Lutzomyia gomezi & 13.9 & Accidental \\
Migonemyia migonei & 8.3 & Accidental \\
Nyssomyia anduzei & 66.7 & Constant \\
Nyssomyia antunesi & 27.8 & Accessory \\
Nyssomyia umbratilis & 91.7 & Constant \\
Psychodopygus ayrozai & 16.7 & Accidental \\
Psychodopygus davisi & 69.4 & Constant \\
Psychododpygus paraensis & 22.2 & Accidental \\
Psychodopygus sq. squamiventris & 50.0 & Accessory \\
\hline
\end{tabular}

(iii) Tabatinga, in rural settlements (2 specimens) [39]. The collection methods adopted in our study made it possible to observe the presence of $N y$. umbratilis not only in the peridomicile but also in the intradomicile, with a total of 61 specimens observed in these ecotopes.
According to Rangel \& Lainson [40], in areas with a high concentration of ACL, it is mistakenly believed that $N y$. umbratilis is adapting to the peridomicile. In the present study, the highest abundance was observed in the forest (F100m location), showing that this species may be approaching environments with a greater human presence. Specimens with Leishmania DNA, however, were collected only in the forest, thereby suggesting the possibility of transmission in this area by this vector only in forest environments.

Species related to Leishmania spp. transmission, $N y$. umbratilis $[L .(V$.$) guyanensis], Ny. anduzei [L .(V)$. guyanensis] and Ps. davisi [L. (V.) naiffi] [2, 41-43], presented high SISA values of $1.0,0.9$ and 0.8 , respectively. In addition, the fact that these species were considered constant according to the constancy index highlights the potential for transmission and partially explains why this disease is endemic to the area, contributing to the higher transmission levels found in Manaus. However, the constancy index has limitations because of the use of a single method of collection; other species that, owing to their biology, are not attracted in abundance by CDC may exhibit errors in classification through the use of this index.

Table 3 Distribution of positive sand fly samples for Leishmania DNA, from Tarumã Mirim Rural Settlement, Manaus Municipality, Amazonas State, Brazil, collected with CDC light traps from May 2015 to April 2016, according to ecotope

\begin{tabular}{|c|c|c|c|c|c|c|}
\hline \multirow[t]{2}{*}{ Species } & \multicolumn{4}{|c|}{ Positive pools by ecotope } & \multirow{2}{*}{$\begin{array}{l}\text { Total of } \\
\text { pools by examined }\end{array}$} & \multirow{2}{*}{$\begin{array}{l}\text { Minimum } \\
\text { infection rate }\end{array}$} \\
\hline & $\mathrm{Id}$ & $\mathrm{Pd}$ & F100m & $\mathrm{F} 400 \mathrm{~m}$ & & \\
\hline Bichromomyia flaviscutellata & - & 1 & 1 & 1 & 11 & 16.7 \\
\hline Bichromomyia olmeca nociva & - & - & 1 & 2 & 23 & 7.5 \\
\hline Evandromyia monstruosa & - & - & 2 & - & 20 & 8.3 \\
\hline Evandromyia sericea & - & 1 & - & - & 21 & 2.8 \\
\hline Lutzomyia gomezi & - & - & 1 & - & 4 & 25.0 \\
\hline Nyssomyia anduzei & - & - & 6 & 3 & 43 & 6.2 \\
\hline Nyssomyia antunesi & 1 & - & - & - & 13 & 5.0 \\
\hline Nyssomyia umbratilis & - & - & 2 & 3 & 60 & 2.7 \\
\hline Psathyromyia aragaoi & - & - & 1 & - & 6 & 11.1 \\
\hline Psathyromyia dreisbachi & - & - & 1 & - & 5 & 20.0 \\
\hline Psathyromyia lutziana & 1 & - & - & - & 1 & 100 \\
\hline Psychodopygus amazonensis & - & - & 1 & 1 & 2 & 100 \\
\hline Psychodopygus ayrozai & - & - & 1 & 1 & 3 & 66.7 \\
\hline Psychodopygus chagasi & - & - & 1 & 1 & 6 & 33.3 \\
\hline Psychodopygus claustrei & - & - & 1 & - & 4 & 16.7 \\
\hline Psychodopygus corossoniensis & - & - & 3 & 3 & 10 & 27.3 \\
\hline Psychodopygus davisi & - & - & 1 & 3 & 33 & 4.2 \\
\hline Psychodopygus hirsutus hirsutus & - & 1 & 1 & 1 & 3 & 42.9 \\
\hline Psychodopygus sq. squamiventris & - & - & - & 2 & 19 & 7.1 \\
\hline Sciopemyia sordellii & 1 & 1 & - & 1 & 63 & 1.4 \\
\hline Trichophoromyia eurypyga & - & - & 1 & - & 14 & 7.1 \\
\hline
\end{tabular}


Specimens of Bi. flaviscutellata and Ny. antunesi in the peridomicile and intradomicile, respectively, were found to contain Leishmania DNA. Bichromomyia flaviscutellata is a vector of $L$. (L.) amazonensis, causing cutaneous leishmaniasis, mucosal leishmaniasis and diffuse cutaneous leishmaniasis in the Amazon [43]. In a study carried out in a campinarana area in Manaus, it was the species with the highest density [44]. Our data showed low abundance of this vector (22 specimens), with only two specimens observed in the peridomicile, thus reducing the chance of humanvector contact and transmission. This species is usually found near the ground biting small rodents, but in areas where it occurs at greater abundance, it can bite humans [45].

Nyssomyia antunesi is a suspected vector of $L$. $(V$.) lindenbergi and of Leishmania spp. in Pará and in some areas of the Colombian Amazon Forest, respectively. In Colombia, this species has developed intradomiciliary habits $[15,43]$. Nyssomyia antunesi is also suspected to be a vector of Leishmania in the municipality of Labrea, Amazonas, where it was found in high abundance in intra- and peridomiciliary locations [15]. Ramos et al. [17] observed that $N y$. antunesi was the most abundant species under similar environmental conditions of a rural settlement, and it was more abundant in the peridomicile. In this study, although this species was found at low abundance in the intradomicile, Leishmania DNA was observed in sand flies collected in this environment, thereby representing a risk of leishmaniasis transmission due to the highly anthropophilic nature of this insect.

Other species that are suspected or proven vectors of Leishmania spp. were observed in this study but are not important transmitters of ACL in Amazonas. Their presence indicates the potential receptivity of the area to other Leishmania spp. Specimens of Ps. ayrozai, Ps. sq. squamiventris, Lu. gomezi and $N y$. antunesi were found to be positive for Leishmania DNA. Other species contained Leishmania DNA and were not related to ACL transmission. While this finding does not mean that these species are transmitting parasites, it does show that parasites are circulating in ecotopes where these species are found.

Among the evaluated ecotypes, differences in species composition and abundance were observed. In the F400m location there was an elevated abundance of phlebotomine species. However, the $\mathrm{F} 100 \mathrm{~m}$ areas showed a greater abundance of species that have already been implicated in the transmission of ACL (confirmed or suspected) and more specimens positive for the presence of Leishmania DNA. A significant difference was not observed in the abundance and diversity of sand flies among these ecotopes, both are forest environments.
The intra- and peridomicile were not significantly different in terms of abundance but differed in terms of diversity indexes. The intradomicile showed a low value for the Shannon's index $\left(\mathrm{H}^{\prime}\right)$ due the predominance of Sc. sordellii (41.5\%) followed by Mi. rorotaensis (23.6\%).

The proximity of forest ecotopes to dwellings where there is a considerable human presence can attract sand flies to peridomicile and intradomicile locations. Phlebotomine sand flies are capable of flying short distances but are attracted by light and seek the blood of humans and synanthropic animals, increasing the probability of chance encounters between humans and vectors.

There have been few studies on natural infection by Leishmania in the Amazonas state, and most involved the dissection of individual sand flies to detect the presence of trypanosomatid forms [10, 11, 16, 39, 46, 47]. The detection of Leishmania using molecular methods such as PCR has been performed in only two other studies of the Amazonas [7, 9]. Silva et al. [9] recorded the presence of Leishmania DNA in Th. ubiquitalis, Ev. apurinan, Ny. umbratilis, Ny. yuilli yuilli, Ps. davisi and Sc. servulolimai in an indigenous settlement in the Labrea municipality. Pereira Júnior et al. [7] observed the presence of Leishmania DNA in Th. ubiquitalis and $P$ s. davisi in terra firme and varzea environments in the Tefé municipality.

In Manaus, information on natural infection by Leishmania is scarce, despite its epidemiological importance for ACL in the Amazonas, which is one of the main areas where this disease is endemic. Arias \& Freitas [10], Arias et al. [11] and Pinheiro et al. [47] detected the presence of Leishmania DNA in $N y$. umbratilis, Ny. anduzei, Bi. flaviscutellata and Bi. olmeca nociva, using the dissection method. This lack of data highlights the relevance of the present study and demonstrates that, until now, there has been no evidence that ACL vectors are becoming increasingly associated with human residences.

While there are more sand flies such as $N y$. umbratilis and other possible vectors in the forest, they were observed closer to environments with a greater human presence, showing that this species may be approaching these environments. In the Tarumã Mirim Rural Settlement, there are about 1,600 residents, with about $70 \%$ of the adults and children exhibiting a history of leishmaniasis (Barbosa, unpublished data). As this area is near the urban area in Manaus and reasonably accessible, there is a large flow of people visiting the settlement on weekends, holidays and during vacation periods. The presence of potential vector species in intradomicile and peridomicile locations, and of Leishmania DNA in species circulating in different environments, contributes to an increased hazard of ACL transmission in this area. 


\section{Conclusions}

There is a high level of species diversity of sand flies in the Tarumã Mirim Rural Settlement. Sand fly species vary across ecotopes and are more abundant in forest ecotopes than in peridomicile ecotopes. Some important species implicated as vectors were found in intradomicile and peridomicile locations due to the structural organization of rural settlements and contributing significantly to an increased hazard of ACL transmission. The detection of Leishmania DNA in species not considered vectors does not mean that these species are transmitting the parasite, but rather that the parasite is circulating in environments where these specimens were found.

\section{Abbreviations}

ACL: American cutaneous leishmaniasis; CDC: Centers for Disease Control and Prevention; DNA: Deoxyribonucleic acid; F100m: Forest $100 \mathrm{~m}$ area; F400m: Forest 400 m area; H': Shannon's index; kDNA: Kinetoplastid DNA; PCR: Polymerase chain reaction; SISA: Standardized Index of Species Abundance

\section{Acknowledgments}

The authors are grateful to the residents of the Tarumã Mirim Rural Settlement, who allowed sample collection on their property. For their help with collection, we thank the FVS-AM entomology team, mainly Leonildo Herculano and Marcos Marques, as well as Flávio Fé (FMT-HVD). We thank Yolanda Noguth (FMT-HVD) for her contribution to the laboratory procedures. We are especially grateful to the late Elcimar Cavalcante Neves for his effort, dedication and participation in all field collection.

\section{Funding}

This research was financially supported by Fundação de Amparo a Pesquisa do Estado o Amazonas (FAPEAM) carried out under the Project "Environmental monitoring in municipalities of the Metropolitan Region of Manaus: air quality and diseases transmitted by arthropods", with approval through the Edital Resolution Nº. 002/2008 - PRÓ-ESTADO.

\section{Availability of data and materials}

The datasets supporting the conclusions of this article are included within the article.

\section{Authors' contributions}

ECSC, ASS, NFF and LSF participated in data collection, laboratory procedures and fieldwork. ECSC, VSS, RAFS, JAOG, HS and MGVBG were involved in interpreting data and preparing manuscripts. WCMT was responsible for creating the map. All authors read and approved the final manuscript.

\section{Ethics approval and consent to participate}

Sampling in the field was conducted under authorization No. 51984-1 of the Biodiversity Information and Authorization System (SISBIO).

\section{Consent for publication}

Not applicable.

\section{Competing interests}

The authors declare that they have no competing interests.

\section{Publisher's Note}

Springer Nature remains neutral with regard to jurisdictional claims in published maps and institutional affiliations.

\section{Author details}

'Universidade do Estado do Amazonas (Programa de Pós-graduação em Medicina Tropical/Programa de Pos-graduação em Clima e Ambiente), Manaus, Amazonas, Brasil. ${ }^{2}$ Fundação de Medicina Tropical Dr. Heitor Vieira Dourado, Manaus, Amazonas, Brasil. ${ }^{3}$ Fundação de Vigilância em Saúde do Estado do Amazonas, Manaus, Amazonas, Brasil. ${ }^{4}$ Instituto de Higiene e Medicina Tropical de Lisboa, Universidade Nova de Lisboa, Lisboa, Portugal.
Received: 6 October 2017 Accepted: 23 February 2018

Published online: 13 March 2018

\section{References}

1. Killick-Kendrick R. The biology and control of phlebotomine sand flies. Clin Dermatol. 1999;17:279-89.

2. Akhoundi M, Kuhls $K$, Cannet A, Votýpka J, Marty P, Delaunay $P$, et al. A historical overview of the classification, evolution, and dispersion of Leishmania parasites and sandflies. PLoS Negl Trop Dis. 2016;10:e0004349.

3. Alvar J, Vélez ID, Bern C, Herrero M, Desjeux P, Cano J, et al. Leishmaniasis worldwide and global estimates of its incidence. PLoS One. 2012;7:e35671.

4. Bailey MS, Lockwood DNJ. Cutaneous leishmaniasis. Clin Dermatol. 2007;25: 203-11.

5. Espir T, Guerreiro TS, Naiff MF, Figueira LP, Soares FV, da Silva SS, et al. Evaluation of different diagnostic methods of American cutaneous leishmaniasis in the Brazilian Amazon. Exp Parasitol. 2016;167:1-6.

6. Maroli M, Feliciangeli MD, Bichaud L, Charrel RN, Gradoni L. Phlebotomine sandflies and the spreading of leishmaniases and other diseases of public health concern. Med Vet Entomol. 2013;27:123-47.

7. Pereira Júnior $A M$, Teles $C B G$, de Azevedo dos Santos AP, de Souza Rodrigues M, Marialva EF, Pessoa FAC, et al. Ecological aspects and molecular detection of Leishmania DNA Ross (Kinetoplastida: Trypanosomatidae) in phlebotomine sandflies (Diptera: Psychodidae) in terra firme and várzea environments in the Middle Solimões Region, Amazonas State, Brazil. Parasit Vectors. 2015;8:180.

8. Shimabukuro PHF, De Andrade AJ, Galati EAB. Checklist of American sand flies (Diptera, Psychodidae, Phlebotominae): Genera, species, and their distribution. ZooKeys. 2017:660:67-106.

9. Silva TRR, Assis MDG, Freire MP, Rego FD, Gontijo CMF, Shimabukuro PHF. Molecular detection of Leishmania in sand flies (Diptera: Psychodidae: Phlebotominae) collected in the Caititu Indigenous Reserve of the Municipality of Lábrea, State of Amazonas, Brazil. J Med Entomol. 2014;51: $1276-82$

10. Arias JR, de Freitas RA. Sobre os vetores de leishmaniose cutânea na Amazônia central do Brasil. 2. incidência de flagelados em flebótomos selváticos. Acta Amaz. 1978;8:387-96.

11. Arias JR, de Freitas RA, Naiff RD, Barrett TV. Observations on the parasite Leishmania mexicana amazonensis and its natural infection of the sand fly Lutzomyia olmeca nociva. Bull Pan Am Health Organ. 1987:21:48-54.

12. Coelho LIC, Paes M, Guerra JA, Barbosa MDG, Coelho C, Lima B, et al. Characterization of Leishmania spp. causing cutaneous leishmaniasis in Manaus, Amazonas, Brazil. Parasitol Res. 2011;108:671-7.

13. Feitosa MAC, Castellón EG. Fauna de flebotomíneos (Diptera: Psychodidae) em fragmentos florestais ao redor de conjuntos habitacionais na cidade de Manaus, Amazonas, Brasil: II. Estratificação horizontal. Acta Amaz. 2004:34:121-7.

14. Barbosa M d GV, Fé NF, Marcião AHR, Silva AP, Monteiro WM, Guerra JA d O. Fauna de flebotomíneos (Diptera: Psychodidae) em um foco de leishmaniose tegumentar americana na área periurbana de Manaus, Estado do Amazonas. Rev Soc Bras Med Trop. 2008:41:485-91.

15. Figueira EAG, Silva G, Chagas EC da S, Shimabukuro PHF. Phlebotomine sandflies (Diptera: Psychodidae) from Lábrea, state of Amazonas, Brazil, with a description of Evandromyia (Aldamyia) apurinan Shimabukuro, Figueira \& Silva, sp. nov. Mem Inst Oswaldo Cruz. 2013;108:280-7.

16. Reis SR, Gomes LHM, Ferreira NM, Nery $L d R$, Pinheiro FG, Figueira $L d P$, et al. Ocorrência de flebotomíneos (Diptera: Psychodidae: Phlebotominae) no ambiente peridomiciliar em área de foco de transmissão de leishmaniose tegumentar no município de Manaus, Amazonas. Acta Amaz. 2013;43:123-6.

17. Ramos WR, Medeiros JF, Julião GR, Ríos-Velásquez CM, Marialva EF, Desmouliére SJM, et al. Anthropic effects on sand fly (Diptera: Psychodidae) abundance and diversity in an Amazonian rural settlement, Brazil. Acta Trop. 2014;139:44-52.

18. Instituto Brasileiro de Geografia e Estatística. 2017. https:/cidades.ibge.gov.br/ brasil/am/manaus/panorama. Accessed 29 Jul 2017.

19. Almeida AF. Análise fitossociológica estrutural e composição florística da área de proteção ambiental margem esquerda do Rio Negro, Manaus - AM [Dissertação de Mestrado]. Manaus: Universidade Federal do Amazonas, Faculdade de Ciências Agrárias, Programa de Pós-Graduação Stricto Sensu em Ciências Florestais e Ambientais; 2012. http://tede.ufam.edu.br/handle/ tede/3038. Accessed 12 Dec 2017. 
20. Costa JR, Soares JEC, Mota AM, Coral ST. Ações integradas em busca da sustentabilidade no Assentamento Tarumã-Mirim, zona rural de Manaus (AM). Rev Bras Agroecol. 2012;7:14-24.

21. Young DG, Duncan MA. Guide to the identification and geographic distribution of Lutzomyia sand flies in Mexico, the West Indies, Central and South America (Diptera: Psychodidae). Gainesville, Florida: Memoirs of the American Entomological Institute, Associated Publishers; 1994.

22. Galati EAB. Morfologia e Taxonomia: Morfologia, terminologia de adultos e identificação táxons da América. In: Rangel EF, Lainson R, editors. Flebotomíneos do Brasil. Rio de Janeiro: Fiocruz; 2003. p. 53-175.

23. Marcondes CB. A proposal of generic and subgeneric abbreviations for phlebotomine sandflies (Diptera: Psychodidae: Phlebotominae) of the world. Entomol News. 2007;118:351-6.

24. Pita-Pereira D d, Souza GD, Pereira T d A, Zwetsch A, Britto C, Rangel EF. Lutzomyia (Pintomyia) fischeri (Diptera: Psychodidae: Phlebotominae), a probable vector of American cutaneous leishmaniasis: detection of natural infection by Leishmania (Viannia) DNA in specimens from the municipality of Porto Alegre (RS), Brazil, using multiplex PCR assay. Acta Trop. 2011;120: 273-5.

25. Reale S, Maxia L, Vitale F, Glorioso NS, Caracappa S, Vesco G. Detection of Leishmania infantum in dogs by PCR with lymph node aspirates and blood. J Clin Microbiol. 1999;37:2931-5.

26. Folmer O, Black M, Hoeh W, Lutz R, Vrijenhoek R. DNA primers for amplification of mitochondrial cytochrome c oxidase subunit I from diverse metazoan invertebrates. Mol Mar Biol Biotechnol. 1994;3:294-9.

27. Roberts DR, Hsi BP. An index of species abundance for use with mosquito surveillance data. Environ Entomol. 1979;8:1007-13.

28. Silveira Neto S, Nakano O, Barbin D, Villa Nova NA. Manual de ecologia dos insetos. São Paulo: Agronômica Ceres; 1976.

29. Paiva BR, Secundino NFC, Nascimento JC, Pimenta PFP, Galati EAB, Junior HFA, et al. Detection and identification of Leishmania species in fieldcaptured phlebotomine sandflies based on mini-exon gene PCR. Acta Trop. 2006;99:252-9

30. Resadore F, Pereira Júnior AM, Carvalho LPC, Santos AP d A d, Teles CBG, Medeiros JF. Phlebotomine sand fly composition (Diptera: Psychodidae) and putative vectors of American Cutaneous Leishmaniasis in Porto Velho Municipality, Western Amazon, Brazil. J Med Entomol. 2017;54:798-803.

31. Arias JR, Freitas RA d. On the vectors of cutaneous leishmaniasis in the central Amazon of Brazil. 3. Phlebotominae sand fly stratification in a terra firme forest. Acta Amaz. 1982;12:599-608.

32. Castellón EG, Arias JR, Freitas RA, Naiff RD. Os flebotomíneos da região amazônica, estrada Manaus - Humaitá, Estado do Amazonas, Brasil (Diptera: Psychodidae: Phlebotominae). Acta Amaz. 1994;24:91-102.

33. Dias-lima AG, Castellon EG, Sherlock I. Flebotomíneos (Diptera: Psychodidae) de uma floresta primária de terra firme da Estação Experimental de Sivicultura Tropical, estado do Amazonas, Brasil. Acta Amaz. 1999;33:303-16.

34. Gomes LHM, Albuquerque MIC, da Rocha LC, Pinheiro FG, Franco AMR. Diversity and distribution of sandflies (Diptera: Psychodidae: Phlebotominae) in a military area in the state of Amazonas, Brazil. Mem Inst Oswaldo Cruz. 2013;108:651-6.

35. Arias JR, Freitas RA d. Flebótomos da Amazônia Central do Brasil. I. Resultados obtidos das capturas feitas com iscas humanas e equinas (Diptera, Psychodidae). Acta Amaz. 1977;7:507-27.

36. Figueira Lde $P$, Zanotti M, Pinheiro FG, Franco AM. Isoenzymatic characterization of human isolates of Leishmania sp. (Kinetoplastida: Trypanosomatidae) from the municipalities of Rio Preto da Eva and Manaus, State of Amazonas. Rev Soc Bras Med Trop. 2008:41:512-4 (In Portuguese).

37. Guerra JA de O, Prestes SR, Silveira H, Coelho LI de ARC, Gama P, Moura A, et al. Mucosal leishmaniasis caused by Leishmania (Viannia) braziliensis and Leishmania (Viannia) guyanensis in the Brazilian Amazon. PLoS Negl Trop Dis. 2011;e980:5

38. Guerra JA de O, Ribeiro JAS, Coelho LI de ARC, Barbosa M das GV, Paes MG. Epidemiologia da leishmaniose tegumentar na Comunidade São João, Manaus, Amazonas, Brasil. Cad Saúde Pública. 2006;22:2319-27.

39. Soares FV, Freitas RA d, Figueira L d P, Franco AMR. Vetores de tripanosomatídeos (Kinetoplastida: Trypanosomatidae) em Tabatinga, Amazonas, Brasil. Acta Bras. 2017;1:23-8

40. Rangel EF, Lainson R. Proven and putative vectors of American cutaneous leishmaniasis in Brazil: aspects of their biology and vectorial competence. Mem Inst Oswaldo Cruz. 2009:104:937-54
41. Ready PD. Biology of phlebotomine sand flies as vectors of disease agents. Annu Rev Entomol. 2013:58:227-50.

42. Gil LHS, Basano SA, Souza AA, Silva MGS, Barata I, Ishikawa EA, et al. Recent observations on the sand fly (Diptera: Psychodidae) fauna of the State of Rondônia, western Amazônia, Brazil: the importance of Psychdopygus davisi as a vector of zoonotic cutaneous leishmaniasis. Mem Inst Oswaldo Cruz. 2003;98:751-5

43. Lainson R. The neotropical Leishmania species: a brief historical review of their discovery, ecology and taxonomy. Rev Pan-Amazônica Saúde. 2010;1:13-32.

44. da Silva PES, Freitas RA d, Silva DF d, Alencar RB. Fauna de flebotomíneos (Diptera: Psychodidae) de uma reserva de campina no Estado do Amazonas, e sua importância epidemiológica. Rev Soc Bras Med Trop. 2010;43:78-81.

45. Shaw JJ, Lainson R, Ward RD. Leishmaniasis in Brazil. VII. Further observations on the feeding habitats of Lutzomyia flaviscutellata (Mangabeira) with particular reference to its biting habits at different heights. Trans R Soc Trop Med Hyg. 1972;66:718-23.

46. Pessoa FAC, Medeiros JF, Barrett TV. Effects of timber harvest on phlebotomine sand flies (Diptera: Psychodidae) in a production forest: Abundance of species on tree trunks and prevalence of trypanosomatids. Mem Inst Oswaldo Cruz. 2007:102:593-9.

47. Pinheiro FG, Luz SLB, Franco AMR. Infecção natural por tripanosomatídeos (Kinetoplastida: Trypanosomatidae) em Lutzomyia umbratilis (Diptera: Psychodidae) em áreas de leishmaniose tegumentar americana no Amazonas, Brasil. Acta Amaz. 2008:38:165-72.

48. Centers for Disease Control and Prevention. Shapefiles. 2017. https://www cdc.gov/epiinfo/support/downloads/shapefiles.html. Accessed 29 Sept 2017.

49. Google. Google Earth. 2017. https://www.google.com/earth/download/gep/ agree.html. Accessed 29 Sept 2017.

\section{Submit your next manuscript to BioMed Central and we will help you at every step:}

- We accept pre-submission inquiries

- Our selector tool helps you to find the most relevant journal

- We provide round the clock customer support

- Convenient online submission

- Thorough peer review

- Inclusion in PubMed and all major indexing services

- Maximum visibility for your research

Submit your manuscript at www.biomedcentral.com/submit

) Biomed Central 